\title{
Changes in glucose tolerance, insulin, serum lipids and lipoproteins in patients with renal failure on intermittent haemodialysis
}

\author{
K. K. Arora \\ M.B., B.S., M.R.C.P. \\ J. A. P. TRAFFord \\ M.B., B.S., M.R.C.P.
}

M. K. AtKInSON*

M.B., B.S., M.R.C.P.

J. SHELDON

M.D., M.R.C.P.

\author{
Renal Unit, Royal Sussex County Hospital, Brighton \\ R. NUNN \\ M.Sc., F.R.I.C., M.R.C.Path. \\ St Francis Hospital, Haywards Heath, Sussex
}

\begin{abstract}
Summary
Fasting serum lipids and lipoprotein patterns, glucose tolerance and serum insulin response to glucose were investigated in eight patients with renal failure on intermittent haemodialysis and five normal controls. The mean 0.5, 1 and $2 \mathrm{hr}$ blood glucose values were significantly higher in patients compared with controls but there was no significant difference between patients and controls in respect of fasting serum insulin levels or the insulin response to glucose. Six of the eight patients showed hypertriglyceridaemia (hyperprebetalipoproteinaemia).

\section{Introduction}

Hyperlipoproteinaemia is a known complication of end-stage renal failure (Bagdade, Porte \& Bierman, 1968; Bagdade, Bierman \& Porte, 1967). In addition, impaired glucose tolerance has been described in patients with chronic renal failure on intermittent haemodialysis (Losowsky \& Kenward, 1968; Bagdade, 1968; Hutchings, Hegstrom \& Scribner, 1966).

In the present study, glucose tolerance and insulin response to glucose, and serum lipids with lipoprotein patterns were investigated in an attempt to determine whether there is any consistent relationship between disturbances of carbohydrate tolerance and lipoprotein patterns in patients with end-stage renal failure.
\end{abstract}

\section{Subjects}

Patients-Eight patients with end-stage chronic renal failure on intermittent haemodialysis were studied as in-patients (Table 1). Their mean age was

\footnotetext{
Requests for reprints: Dr J. Sheldon, Royal Sussex County Hospital, Brighton.

* Present address: Royal Marsden Hospital, Sutton,
}

38 years (range $22-49$ years). There were six females and two males. All patients were within $10 \%$ of ideal body weight (Metropolitan Life Insurance Company Statistical Bulletin, 1959). The creatinine clearance of each patient was less than $1.5 \mathrm{ml} / \mathrm{min}$. The mean duration of dialysis was $\mathbf{2 5 . 7}$ months (range 2-50 months). There was no evidence of any other systemic disease and there was no family history of diabetes mellitus. No patient had evidence of infection of the shunt or elsewhere at the time of study. All patients were dialysed twice weekly $(18 \mathrm{hr} /$ week) using a coil dialyser. They were taking $60 \mathrm{~g}$ of protein/day and carbohydrate constituted $40-45 \%$ of the total calorie intake.

Controls-Five healthy subjects working in the renal unit acted as controls. Their mean age was 29 years (range 21-42 years). There were three females and two males. All were within $10 \%$ of ideal body weight.

\section{Methods}

Patients and controls were on a $300 \mathrm{~g}$ carbohydrate diet for 3 days before each test. Blood samples were taken after a 10-hr overnight fast, in the resting state and without applying a tourniquet, for the estimation of glucose, insulin and serum lipids. Blood samples were taken 0.5, 1 and $2 \mathrm{hr}$ after $50 \mathrm{~g}$ of oral glucose for blood glucose and insulin.

Blood glucose was estimated by a glucose oxidase method (Werner, Roy \& Weilinger, 1970) using an AutoAnalyzer. Serum cholesterol was estimated by a method using the modified Leiberman-Burchard reaction (Abell et al., 1952) and the serum triglycerides were determined by an enzymatic method (Eggstein, 1966). Lipoprotein patterns were assessed qualitatively using an agarose-gel method (Fredrichson, Levy \& Lees, 1967). 
TABle 1. Age, sex, duration of dialysis and serum lipids in patients

\begin{tabular}{|c|c|c|c|c|c|c|c|c|c|}
\hline Patient & $\begin{array}{c}\text { Age } \\
\text { (years) }\end{array}$ & Sex & $\begin{array}{l}\text { weight } \\
(\mathrm{kg})\end{array}$ & $\begin{array}{c}\% \text { of } \\
\text { desirable } \\
\text { weight }\end{array}$ & Diagnosis & $\begin{array}{l}\text { Duration of } \\
\text { haemodialysis } \\
\text { (months) }\end{array}$ & $\begin{array}{c}\text { Serum } \\
\text { cholesterol } \\
(\mathrm{mg} / 100 \mathrm{ml}) \\
\text { (normal range } \\
190-260)\end{array}$ & $\begin{array}{c}\text { Serum } \\
\text { triglycerides } \\
(\mathrm{mg} / 100 \mathrm{ml}) \\
\text { (normal range } \\
95-160)\end{array}$ & $\begin{array}{l}\text { Lipoprotein } \\
\text { pattern } \\
\text { (Fredrickson } \\
\text { classification) }\end{array}$ \\
\hline M.L. & 22 & F & 50 & 100 & $\begin{array}{l}\text { Chronic pyelo- } \\
\text { nephritis* }\end{array}$ & 50 & 282 & 216 & Type IV \\
\hline M.B. & 39 & $\mathrm{~F}$ & 55 & 102 & $\begin{array}{l}\text { Proliferative } \\
\text { glomerulo- } \\
\text { nephritis }\end{array}$ & 18 & 205 & 59 & Normal \\
\hline M.J. & 30 & $\mathbf{F}$ & 54 & 106 & $\begin{array}{l}\text { Henoch-Schönlein } \\
\text { purpura }\end{array}$ & 12 & 245 & 110 & Normal \\
\hline D.G. & 37 & $\mathbf{M}$ & 70 & 100 & $\begin{array}{c}\text { Chronic pyelo- } \\
\text { nephritis* }\end{array}$ & 46 & 280 & 260 & Type IV \\
\hline R.H. & 48 & $\mathbf{M}$ & 54 & 93 & Polycystic kidneys* & 36 & 286 & 271 & Type IV \\
\hline M.G. & 49 & $\mathrm{~F}$ & 56 & 100 & $\begin{array}{l}\text { Chronic glomerulo- } \\
\text { nephritis }\end{array}$ & 20 & 264 & 400 & Type IV \\
\hline B.B. & 38 & F & 60 & 100 & $\begin{array}{l}\text { Malignant hyper- } \\
\text { tension }\end{array}$ & 2 & 206 & 284 & Type IV \\
\hline I.B. & 45 & $\mathrm{~F}$ & 46 & 93 & $\begin{array}{l}\text { Chronic glomerulo- } \\
\text { nephritis }\end{array}$ & 22 & 240 & 226 & Type IV \\
\hline
\end{tabular}

* Anephric.

TABLE 2. Mean blood glucose and mean serum insulin values in eight patients and five controls

\begin{tabular}{|c|c|c|c|c|c|c|}
\hline \multirow{2}{*}{$\begin{array}{c}\text { Time } \\
(\mathrm{hr})\end{array}$} & \multicolumn{3}{|c|}{ Mean blood glucose $(\mathrm{mg} / 100 \mathrm{ml})$} & \multicolumn{3}{|c|}{ Mean serum insulin $(\mu \mathrm{U} / \mathrm{ml})$} \\
\hline & Patient & Control & $P$ & Patient & Control & $P$ \\
\hline $\begin{array}{l}\text { Fasting } \\
0 \cdot 5 \\
1 \\
2\end{array}$ & $\begin{array}{ll}64 \cdot 23 & \mathrm{SE} \pm 2 \cdot 85 \\
94 \cdot 15 & \mathrm{SE} \pm 5 \cdot 18 \\
97 \cdot 38 & \mathrm{SE} \pm 5 \cdot 89 \\
82 \cdot 77 & \mathrm{SE} \pm 6 \cdot 08\end{array}$ & $\begin{array}{ll}65.57 & \mathrm{SE} \pm 5 \cdot 20 \\
77.14 & \mathrm{SE} \pm 4.97 \\
63.00 & \mathrm{SE} \pm 3.01 \\
61.00 & \mathrm{SE} \pm 4.89\end{array}$ & $\begin{array}{l}>0.1 \\
<0.05 \\
<0.001 \\
<0.05\end{array}$ & $\begin{array}{rl}8.71 & \mathrm{SE} \pm 1 \cdot 58 \\
33.21 & \mathrm{SE} \pm 5.97 \\
37.31 & \mathrm{SE} \pm 6.02 \\
22.84 & \mathrm{SE} \pm 6.50\end{array}$ & $\begin{array}{rl}7.85 & \mathrm{SE} \pm 1.65 \\
33.71 & \mathrm{SE} \pm 6.75 \\
33.14 & \mathrm{SE} \pm 10.97 \\
14.43 & \mathrm{SE} \pm 4.24\end{array}$ & $\begin{array}{l}>0 \cdot 1 \\
>0 \cdot 1 \\
>0 \cdot 1 \\
>0 \cdot 1\end{array}$ \\
\hline
\end{tabular}

All the tests were repeated at least once in all the patients and controls.

\section{Results}

The mean glucose and serum insulin values during glucose tolerance tests are shown in Table 2, Figs. 1 and 2.

Table 1 shows the results of serum lipids in the patients, and the normal range in our laboratory.

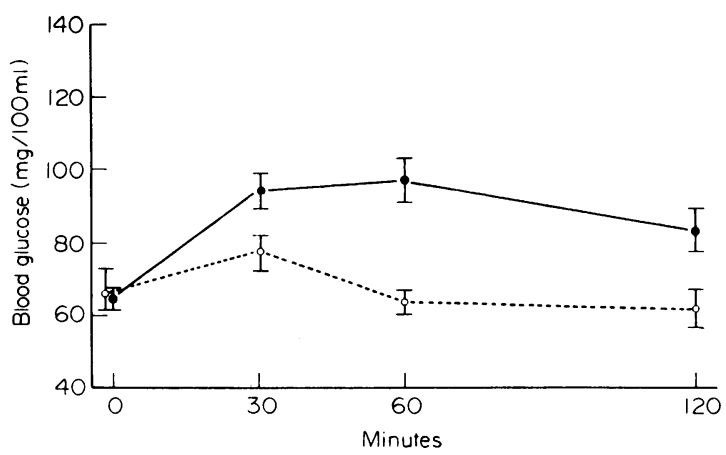

FIG. 1. Mean blood glucose values of eight renal patients (solid line) and five controls (dashed line) following $50 \mathrm{~g}$ glucose. Bars indicate standard error of means.

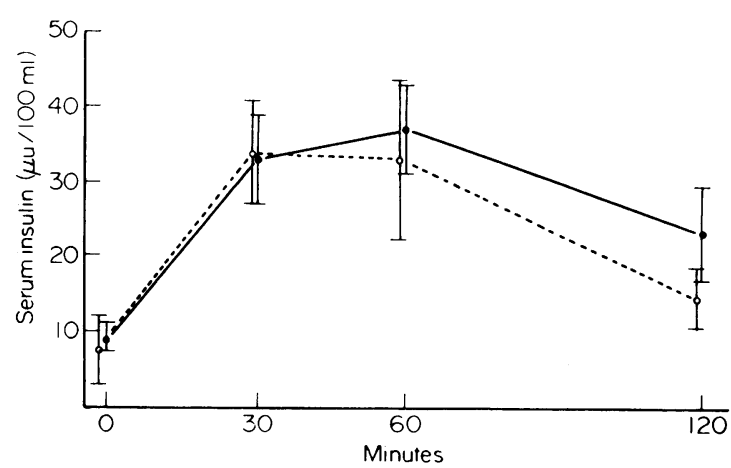

FIG. 2. Mean insulin values of eight renal patients (solid line) and five controls (dashed line) following $50 \mathrm{~g}$ of glucose. Bars indicate standard error of means.

Serum cholesterol was within the normal range in five patients and was marginally raised in the other three. The mean serum cholesterol was $227 \mathrm{mg} /$ $100 \mathrm{ml}(\mathrm{SE} \pm 31)$ as compared with a level of $211.5 \mathrm{mg} / 100 \mathrm{ml}(\mathrm{SE} \pm 10.0)$ in the controls which is not a significant difference $(P>0 \cdot 1)$.

The serum triglyceride levels were significantly raised in six of the eight patients, the mean in the eight patients being $228 \mathrm{mg} / 100 \mathrm{ml}(\mathrm{SE} \pm 31)$ as 
compared with $108.4 \mathrm{mg} / 100 \mathrm{ml}(\mathrm{SE} \pm 13 \cdot 1)$ in the controls $(P<0.01)$.

The plasma lipoproteins assessed qualitatively from the electrophoretic patterns conformed with the lipid measurements, i.e. the six patients who had hypertriglyceridaemia showed Type IV hyperlipoproteinaemia according to Fredrickson's classification (Fredrickson et al., 1967).

\section{Discussion}

Raised fasting immunoreactive insulin levels (Bagdade et al., 1968; Bagdade et al., 1967; Rabinowitz \& Zierler, 1968), hypertriglyceridaemia (Bagdade et al., 1968; Losowsky \& Kenward, 1968; Hollister, Overall \& Snow, 1967), increased insulin levels after glucose (Bagdade et al., 1968; Losowsky \& Kenward, 1968; Hutchings et al., 1966; Karam, Grodsky \& Forsham, 1963; Kreisberg et al., 1967; Perley \& Kepnis, 1963; Yalow \& Berson, 1960) and a high frequency of carbohydrate intolerance (Bagdade et al., 1968; Cohen, 1957; Ogilvie, 1935; Perkoff et al., 1958; Cerletty \& Engbrung, 1967; Horton, Johnson \& Lobovitz, 1968) have been described in patients with uraemia and in obesity. In contrast to those of other workers such as Bagdade et al. (1968) all our patients had fasting immunoreactive insulin and fasting blood glucose levels within the normal range. Though $0.5,1$ and $2 \mathrm{hr}$ blood glucose values were significantly higher than in controls, the absolute levels recorded in our patients were much lower than in other series and all the glucose tolerance curves were within the normal range. This may be related to the longer duration (mean 25.7 months) of haemodialysis, as there is evidence of reversibility of glucose intolerance in patients on intermittent haemodialysis (Hampers et al., 1966; Alfrey et al., 1967; Westervelt \& Schreiner, 1962). Hutchings' patients however still showed glucose intolerance 4 years after being on haemodialysis (Hutchings et al., 1966).

Hypertriglyceridaemia (hyperprebetalipoproteinaemia, Type IV Fredrickson's classification) was observed in six of the eight patients in accordance with the findings of other workers (Bagdade et al., 1968; Losowsky \& Kenward, 1968; Evens \& Ostrander, 1967; Harlan et al., 1967; Hollister et al., 1967). This hypertriglyeridaemia may be due either to increased production or diminished removal of plasma triglycerides, or to a combination of both mechanisms.

Hypertriglyceridaemia resulting probably from increased synthesis of prebetalipoprotein has been shown to be associated with elevated fasting circulating immunoreactive insulin in non-uraemic subjects (Bagdade et al., 1968; Bagdade, 1968; Bierman \& Porte, 1968; Reaven et al., 1967). The same relationship between triglycerides and circulating fasting insulin was shown in haemodialysed patients by Bagdade et al. (1968). But the presence of normal fasting insulin levels and a normal insulin response to glucose in our patients suggests that hyperinsulinaemia cannot be a major factor in the pathogenesis of hypertriglyceridaemia seen in patients on maintenance haemodialysis.

Diminished peripheral removal of lipids may play an important part in hypertriglyceridaemia. Subnormal post-heparin lipolytic activity has been demonstrated in uraemia (Bagdade et al., 1968; Boyer \& Scheig, 1970) with or without dialysis. This post-heparin lipolytic activity seems to reflect tissue levels of lipoprotein lipase, an enzyme which plays an important part in the removal of triglycerides. This low activity may be either due to true low levels of lipoprotein lipase or the presence of an inhibitor of lipoprotein lipase. The fact that three of our patients who have been haemodialysed for 3 years still showed hypertriglyceridaemia throws doubt on the existence of this inhibitor or it suggests such an inhibitor is not dialysable.

\section{Acknowledgments}

We wish to thank Mr J. Cook of the Biochemistry Department for technical help. We are especially indebted to $\mathrm{Mr} \mathrm{C}$. Hallet for the insulin assays and Mr G. Cowdrey for the lipoprotein electrophoresis.

\section{References}

Abell, L.L., Levy, N.N., Brodie, B.B. \& Kendall, F.E. (1952) A simplified method for the estimation of total cholesterol in serum and demonstration of its specificity. Journal of Biology and Chemistry, 195, 357.

Alfrey, A.C., Sussman, M.E. \& Holmes, J.H. (1967) Changes in glucose and insulin metabolism induced by dialysis in patients with chronic uraemia. Metabolism, 16, 733.

BAGDADE, J.D. (1968) Lipaemia, a sequela of chronic renal failure and haemodialysis. American Journal of Clinical Nutrition, 21, 426.

Bagdade, J.D., Bierman, E.L. \& Porte, D. (1967) The significance of basal insulin in the evaluation of the insulin response to glucose in diabetic and non-diabetic subjects. Journal of Clinical Investigation, 46, 1549.

Bagdade, J.D., Porte, D., Jr \& Bierman, E.L. (1968) Hypertriglyceridaemia. A metabolic consequence of chronic renal failure. New England Journal of Medicine, 279, 181.

Bierman, E.L. \& Porte, D. (1968) Carbohydrate intolerance and lipaemia. Annals of Internal Medicine, 68, 926.

Boyer, J.L. \& Scheig, R.L. (1970) Inhibition of postheparin lipolytic activity in uraemia and its relationship to hypertriglyceridaemia. Proceedings of the Society of Experimental Biology and Medicine, 134, 603.

Cerletty, J.M. \& Engbrung, N.H. (1967) Azotaemia and glucose intolerance. Annals of Internal Medicine, 66, 1097.

CoHen, B.D. (1957) Abnormal carbohydrate metabolism in renal disease. Blood glucose unresponsiveness to hypoglycaemia, epinephrine and glucagon. Annals of Internal Medicine, 57, 204. 
Eggstein, M. (1966) Eine neue Bestimmung der Neutrapette in Blutserum und Gewebe, II, Mitteilung. Zuverlassigkeit der Methode, endere Neutralfettrestimmungen, Normalwerte für Triglyceride und Glycerin im menschlichen Blut. Klinische Wochenschrift, 44, 267.

Evans, J.G. \& Ostrander, L.D. (1967) Fasting serum triglycerides. Concentration and distribution of subcutaneous fat. Lancet, i, 761.

Fredrickson, D.S., Levy, R.I. \& LeES, R.S. (1967) Fat transport in lipoproteins. Integrated approach to mechanisms and disorders. New England Journal of Medicine, 276, 34, 94, 148, 215.

Hales, C.N. \& Randle, P.J. (1963) Immuno-assay of insulin with insulin antibody precipitate. Biochemical Journal, 88, 137.

Hampers, C.L., Soelander, J.S., Doak, P.B. \& Merrill, J.P. (1966) Effect of chronic renal failure and haemodialysis on carbohydrate metabolism. Journal of Clinical Investigation, 45, 1719.

Harlan, W.R., Oberman, A., Mitchell, R.E. \& Graybiel, A. (1967) Constitutional and environmental factors related to serum lipid and lipoprotein levels. Annals of Internal Medicine, 66, 540.

Hollister, L.E., Overall, J.E. \& SNow, H.L. (1967) Relationship of obesity to serum triglyceride, cholesterol and uric acid, and to plasma-glucose levels. American Journal of Clinical Nutrition, 20, 777.

Horton, E.S., Johnson, C. \& Lobovitz, H.E. (1968) Carbohydrate metabolism in uraemia. Annals of Internal Medicine, 68, 63.

Hutchings, R.H., Hegstrom, R.M. \& SCribner, B.H. (1966) Glucose intolerance in patients on long-term intermittent dialysis. Annals of Internal Medicine, 65, 275.
Karam, J.H., Grodsky, G.M. \& Forsham, P.H. (1963) Excessive insulin response to glucose in obese subjects as measured by immuno-chemical assay. Diabetes, 12, 197.

Kreisber, R.A., Boshell, B.R., DiPlacido, J. \& Roddam, R.F. (1967) Insulin secretion in obesity. New England Journal of Medicine, 276, 314.

Losowsky, M.S. \& KenwaRd, D.H. (1968) Lipid metabolism in acute and chronic renal failure. Journal of Laboratory and Clinical Medicine, 71, 736.

OGILviE, R.J. (1935) Sugar tolerance in obese subjects. A review of sixty-five cases. Quarterly Journal of Medicine, 4, 345.

Perkoff, G.T., Thomas, C.L., Newton, J.D., Sellman, J.C \& TYleR, F.H. (1958) Mechanism of impaired glucose tolerance in uraemia and experimental hyperazotaemia. Diabetes, 7, 375.

Rabinowitz, D. \& Zierler, K.L. (1968) Forearm metabolism in obesity and its response to intra-arterial insulin characterization of insulin resistance and evidence for adaptive hyperinsulinism. Journal of Clinical Investigation, 41, 2173.

Reaven, G.M., Lerner, R.L., Stern, M.P. \& Farquhar, J.W. (1967) Role of insulin in endogenous hypertriglyceridaemia. Journal of Clinical Investigation, 46, 1756.

WeRNER, W., REY, H.G. \& Wielinger, H.Z. (1970) Uber die Eigenschaften Eines Neuen Chromogens für die Blutzuckerbestimmung Nach der GOD/POD-Methode. Analyst. Chem., 252, 224.

Westervelt, F.B., Jr. \& Schreiner, G.E. (1962) The carbohydrate intolerance of uraemic patients. Annals of Internal Medicine, 57, 266.

YALOW, R.S. \& BERSON, S.A. (1960) Immunoassay of endogenous plasma insulin in man. Journal of Clinical Investigation, 39, 1157. 